\title{
Investigation of Judicial Service Quality and Customer Satisfaction: The Case of Dire Dawa City Courts, Ethiopia
}

\author{
BINIYAM KEBEDE DESTA \\ Lecturer of Management, College of Business (Department Head of MBA) \\ Addis Ababa Medical and Business College, PO Box: 3111, Dire Dawa, Ethiopia
}

\begin{abstract}
This study is conducted to examine Courts Quality Service, Service Delivery and Customer Satisfaction in City Courts. The study was used the primary and secondary source of data and data was collected from 282 sample through a survey questionnaire. Different descriptive statistics, Chi-Squared test, SERVQUAL Model, and logistic regression were used to carry out the research. From 282 study participants, $216(77 \%)$ were males and $66(23 \%)$ were females. The SERVQUAL result depicted that responsiveness is the most important factor to have a positive and significant effect on customer satisfaction followed by reliability, assurance, empathy, and tangibility. The overall satisfaction analysis result showed that $73 \%$ customers were satisfied by the City courts service. From the logistic regression, the City Courts are provide more service on the reliability dimension, assurance dimension, and minimizing of visiting frequency to the customer would increase the satisfaction of customer. Conferring inclusive jurisdictional power that stands by itself and Establishing Cassation Bench in Appellate Court of the City resolves the problems of dissatisfaction of Courts service delivery.
\end{abstract}

Keywords: Service quality, customer satisfaction, City courts in Dire Dawa City

DOI: $10.7176 / J L P G / 84-01$

Publication date: April $30^{\text {th }} 2019$

\section{Introduction}

\subsection{Background of the Study}

The justice sector includes the institutions for the administration of justice, and it should ensure that laws are enforced, the legal system is implemented, social security is promoted, and that social cohesion is guaranteed. A well-functioning justice sector promotes legal certainty, resolves conflicts and regulates the exercise of executive authority. On the other hand, a dysfunctional justice sector encourages human insecurity and impedes economic development.

The 1995 Federal Democratic Republic of Ethiopia (FDRE) Constitution of Ethiopia provides the legal basis for establishment of Federal state structure that consists of nine Regional States and two city administrations. The Federal, Regional States and city administrations have their own legislative, judiciary and executive branches of government. The judicial system can be defined as the governmental branch responsible for enforcing the law, interpreting, adapting to concrete cases and solving disputes. Judicial power is shared between the Federal Government and the Regional States. Article 78 of the Constitution creates three levels of courts in the Federal and Regional States i.e. First Instance Court (FIC), High Court (HC), and Supreme Court (SC) respectively. In the Charter of Dire Dawa Administration Proclamation No.416 /2004, a two level Municipal Courts are established, namely First Instance Court (FIC) and Appellate Court (AC) that exercise a municipal jurisdiction. There is a cassation bench within the Appellate court. Besides there are social courts whose function is based on traditional social values. District Social Courts shall have the jurisdiction over cases regarding property and money claims of an amount not exceeding 100 US dollars, and other civil jurisdiction which shall be determined by law according to Article 41 of the Charter. Any person who is dissatisfied by the decision of social courts may appeal to the First Instance Court of the City.

This study discusses only some of those concerns in its focus on the delivery of services in the Dire Dawa City Court and not in law. An essential component of this service quality enquiry is the delivery of on-time services in the First Instance Court (FIC) and Appellate Court (AC) that exercise what modes of service delivery should be utilized. Dissatisfied customer in the private sector can simply reject the unsatisfactory provider and look to someone else to provide the desired services. In this environment, the laws of the market ensure that providers constantly meet the needs and desires of consumers. Many of the deficiencies in the administration of justice may be addressed by proper allocation of sufficient resources. According to World Bank (2013), in the last two decades, the Ethiopian Public Service institutions improved performance and service delivery by implementing various reform tools and restructuring instruments including Business Process Reengineering (BPR) at federal, regional, and city administration levels in almost all public institutions. The Business Process Reengineering (BPR) was instrumental in clarifying organizations' strategic visions, missions, mandates, and products, and enhancing their top leadership's appreciation of strong institutions simplifying work processes and requirements, which resulted in substantially shorter transaction times for most services; developing service standards establishing important flat structures and offices as well as decentralizing tasks to lower levels of government, establishing one-stop shops 
and enhancing customer orientation in public services. Similarly, the Dire Dawa City Court has inaugurated experience in implementing various reform programs. Hence, measuring court service delivery and customer satisfaction is essential to enhance courts' ability to render high quality of cost-effective and efficient service to customers.

\subsection{Statement of the problem}

It is the obligation of every state to ensure that the judiciary is indeed an independent arm of the government. It continues to state that while a claim can therefore be made that the primary task of the courts is to maintain the rule of law, it should immediately be appreciated that various factors affect service delivery in the courts. Kameri (2011), said for the rule of law to be realized, there must be suitable "application mechanisms", including an independent and professional judiciary, easy access to litigation and reliable enforcement agencies. However judicial system of Ethiopia has been grappled with a crisis of performance such as unwanted lengthy proceedings, backlog of pending cases, times and money invested to get speedy dispensation of justice (World Bank, 2004). According to the Comprehensive Justice System Reform Program Baseline Study (2005), the Ethiopian justice system has the following core problems: "Firstly, it is neither accessible nor responsive to the needs of the poor. Secondly, serious steps to tackle corruption, abuse of power and political interference in the administration of justice have yet to be taken. Thirdly, inadequate funding of the justice institutions aggravates most deficiencies of the administration of justice". This creates obstacles in the promotion and protection of human and democratic rights, inefficiencies in law enforcement as well as in the administration of justice. The situation in Dire Dawa City Court is akin to the above attributes. Though the City Courts have implemented various reform tools to modernize and enhance quality services to its customers during the past eight years; the 2002 G.C revised BPR document identified causes of customer dissatisfaction such as; problem of delay to dispense cases, lack of accessibility, and lack of effectiveness, rent seeking activity, lack of transparency and accountability. Hence, Dire Dawa City Courts as a part of the country's legal system is not free from the above insufficiencies.

Service quality is an overall result similar to attitude towards the service and generally accepted as a predecessor of overall customer satisfaction (Zeithaml \& Bitner, 1996). Customers are the corner stone of the service provider in that without customer it is difficult to assure sustainable continuity and growth of organizations. For this reason, Dire Dawa City Court has the responsibility to provide efficient service to clients and achieve the goal of their mission. To this end, the administration has been introducing various reforms to bring about a remarkable change that ensure expectations of customers. This research is conducted to find out the quality of service provided by the Dire Dawa City Court, how do its customers perceive the service provided by the city court and also the research conducted to understand the service gap and service quality provided by the city court using SERVQUAL measures to determine service quality and customer satisfaction. SERVQUAL scale is the measures of service quality based on the gap between expectation and perception. Within SERVQUAL model there are five specific dimensions of service quality: tangibles, reliability, responsiveness, assurance and empathy (Parasuraman, Zeithaml \& Berry, 1988). Therefore, the problem addressed in this study is to investigate the extent to service quality dimensions affect the customer satisfaction of Dire Dawa City Court, in Dire Dawa Administration, Ethiopian.

\subsection{Research Questions}

The following research questions shall be answered by this study.

1. Do customers' perceive that they receive satisfactory overall service quality from the Dire Dawa City Court in the SERVQUAL dimension of service quality they regard as most important?

2. Do demographic profiles of customers' perceive that differences in service quality level from Dire Dawa City Court?

\subsection{General Objective}

The main objective of this study is to analyze service delivery and customer satisfaction in Dire Dawa City court. 1.4.1. Specific Objectives

The following are specific objectives of the research.

1. Measure customers' responses to questions that will test both their expectation of service quality and their perception of the service quality experience;

2. Identify customers' assessment of the relative importance of the dimensions of service quality; and measure customers' expectations and perceptions of the SERVQUAL dimensions of service quality in the Dire Dawa City Court,

3. To analyze whether demographic profile of Dire Dawa City Court leads to differences in perceive that they receive overall service quality level, Variables like gender, age, marital status, education level and frequency for cases. 


\subsection{Significant of the study}

This study has paramount significance to decision makers, courts manager, stakeholders and practitioners in different ways.

- To management of courts', the findings of the study provide viewpoint for evaluating the level of customer satisfaction associated with the services they are delivering.

- The results of the study also provide empirical support for management decisions in the service delivery processes and develop a justifiably valid and reliable guide to designing workable service delivery improvement strategies to enhance customer satisfaction.

- The results of the study provide invaluable insights to the future successful service delivery by identifying the major determinant factors and the root causes of the problems. Accordingly it provides policy makers and managers of courts' with feedback that was allowing them to prioritize their efforts and it will serve as a basis for further studies on the issue.

\subsection{Limitations of the Study}

Conducting successful and unbiased research is a challenging task. It requires the commitment of the researcher and the respondent and adequate resources. The research is also geographically limited to Dire Dawa City Courts; the service delivery of the courts' have impact on those customers served in the City Courts' rather than those served in other Courts' in the same City . Moreover, the outcome of the study is mainly dependent on the individual responses of the respondents who participate in the study. So the result may not be generalized beyond the City Courts customer. The limitations of this study results delimited to the five service delivery dimensions of SERVQUAL model to measure customer satisfaction in the City Courts.

\section{LITERATURE REVIEW}

These several reports mentioned itemized a damning list of complaints about the inefficiencies and dysfunction of the justice system without characterizing any of them as service quality issues. Service quality issues are included an academic literature, but the literature has concentrated on hospitality management (Crick \& Spencer, 2011; Gilbert et al., 2004), information systems (Golding, 2005; 2011; Golding, Donaldson, Tennant, \& Black, 2008), and institutional change (Schoburgh, 2014).

\subsection{Service Quality}

Three decades ago, when Parasuraman et al. (1985) first attempted to develop a conceptual model of service quality, they complained that "... the literature on service quality is not yet rich enough to provide a sound conceptual foundation for investigating service quality." This is certainly no longer the case. Parasuraman et al. (1985) developed the conceptual model and refined the SERVQUAL scale (Parasuraman et al., 1991b, 1988; 1993). Adapting the SERVQUAL scale to the measurement context improves its predictive validity; conversely, the predictive validity of SERVPERF is not improved by context adjustments. In addition to, measures of services quality gain predictive validity when used in less individualistic cultures, non-English speaking countries, and industries with an intermediate level of customization (Carrillat et al., 2007). The original SERVQUAL scale was developed in five service industries in the private sector. Parasuraman, Zeithaml and Berry (1985) sought originally to capture ten dimensions of service quality, but in later studies reduced these to five (Parasuraman et al., 1988; Zeithaml et al., 1990). Identifying five dimensions may not be suitable or possible in all cases. Some research projects have relied on fewer dimensions (Chakrapani, 1998). It has been suggested that service quality "... is best represented as an aggregate of the discrete elements from the service encounter," which may include these five dimensions as well as others (Carrillat et al. 2007, Cronin and Taylor, 1992 and Parasuraman et al., 1985).

\subsection{Measuring Service Quality}

Lam and Woo (1997) classified them as the American school and the Scandinavian school of thought. The Nordic model, or Scandinavian school, is associated with Grönroos $(1984,1990,2000,2001)$ and the American model or school, is associated with Parasuraman et al., (1985); Berry et al., (1988) and Zeithaml et al., (1996).

The American model also incorporated two different approaches to service quality measures. The first is based on the disconfirmation paradigm where satisfaction was seen as, "a function of the disconfirmation of performance from expectation” (Oliver, 1980, cited by Lee, Lee, \& Yoo, 2000). In Parasuraman et al. (1985) application of this model, service quality is assessed as the difference between the expectation of the service and the perception of the service. This is the gap model and it is described as the "confirmation and disconfirmation of expectations approach" With this approach, the more one's perceptions exceed that which was expected, the better rated is the service; conversely, the more one's expectations exceed that which is perceived, the worse the service is considered to be (Parasuraman et al., 1985). SERVQUAL is built on this paradigm (Parasuraman et al., 1991a, 1988), and it has found numerous applications as a service quality measure (Babakus \& Boller, 1992; Brysland \& Curry, 2001; Donnelly, Mike, \& Shiu et al., 1999; Donnelly et al., 2006; Donnelly, Wisniewski, Dalrymple \& 
Curry, 1995; Dyke et al., 1999; Lam \& Woo, 1997; Parasuraman et al., 1991b, 1988; Weekes, Scott, \& Tidwell, 1996; Wisniewski, 2001a, 2001b; Wisniewski \& Donnelly, 1996). Moreover, it continues to be very popular as a service quality measure across many cultures (Aghamolaei et al., 2014; Musah et al., 2015; Ogunnowo, Olufunlayo, \& Sule, 2015; Roslan, Nor, \& Wahab, 2015). The instrument has been described as the most commonly used tool for measuring service quality.

The second approach of the American model to service quality is based on the performance paradigm. The assumption is that the expectation of service is always qualified or conditioned by the service received and therefore in measuring service quality expectations are ignored, and only the perception or performance questions are considered (Cronin \& Taylor, 1992). The SERVPERF instrument is built on this paradigm, and this too has its full share of adherents (Al Khattab \& Aldehayyat, 2011; Bayraktaroglu \& Atrek, 2010; Carrillat, Jaramillo, \& Mulki, 2007; Cronin \& Taylor, 1994; McAlexander, Kaldenberg, \& Koenig, 1994). Both frameworks are similar, SERVQUAL measuring expectations and perceptions, each on a 22-item scale, while SERVPERF measures perceptions, using only the perception battery of questions.

\subsection{Multidimensionality}

There is an additional difference between SERVQUAL and SERVPERF. The latter treats service quality as one dimensional. This is referred to as overall service quality (OSQ). SERVQUAL, on the other hand measures OSQ, and further breaks down the scale into several sub-categories or service quality dimensions (SQDs). There is still debate whether it is necessary to rely on the multidimensional formulation of service quality, or even whether it is desirable to use the gap between expectation and perception as a measure (Cronin \& Taylor, 1992; Finn \& Lamb, 1991). The literature provides support for both sides of the debate (Durvasula, Lysonski, \& Mehta, 1999), and some studies have treated SERVPERF as a multidimensional measure (Al Khattab \& Aldehayyat, 2011)

\subsection{Applying Service Quality Measures to Public Service}

Rhee and Rha (2009) argued that since the 1990s, service quality has been regarded as critical for reinventing the public sector. At the same time it was recognized that, "Adapting quality management approaches to the public sector has not been particularly easy" (Brysland \& Curry, 2001). Assessing the quality of public services, by the nature of the public services environment, is just difficult (Donnelly et al., 2006). However, there is now a rich body of scholarship applying service quality measures to the delivery of public services (Carvalho, Brito, \& Cabral, 2010; Wisniewski, 2001b; Wisniewski \& Donnelly, 1996). The early applications were not all satisfactory. More recent applications of SERVQUAL to the public services have been much more successful. These include citizens service centers in Greece (Chatzoglou et al., 2013), public health care facilities in Brazil, Greece and Nigeria (Ogunnowo et al., 2015; Rocha et al., 2013), public Hospitals in Iran and Saudi Arabia (Aghamolaei et al., 2014), public physiotherapy service in Brazil (Almeida et al., 2013), and public transport in South Africa and Turkey (Govender, 2016). Rhee and Rha (2009) complained that for the most part, the literature directly applied the five SERVQUAL dimensions of service quality without exploring or validating these dimensions in the public sector and that only a few studies identified other dimensions such as equity and feedback, which are important to public services. Public services relationships are unique and distinct from private services relationships. However, the issues identified by Rhee and Rha (2009) are relevant to where members of the public directly interact with the public service agency to receive a benefit.

\subsection{Understanding the Gaps Model}

The SERVQUAL gaps model seeks to measure service quality as "...the calculated difference between customer expectations and performance perceptions of a service encounter" (Carrillat et al. 2007). As such, the model identifies five gaps that account for unsuccessful service quality delivery. Since the development (Parasuraman et al., 1985) and refinement (Parasuraman et al., 1991b) of the conceptual service quality model, it has assumed increasing importance in identifying service quality gaps in the delivery structure of many types of services providers (Deshwal, 2011; Johns \& Tyas, 1996; Ogunnowo et al., 2015; Xianying \& Qinhai, 2007). The conceptual model of service quality, Zeithaml et al. (1990) identified five gaps. These service quality gaps are Gap 1, the management perception gap; Gap 2, the quality specification gap; Gap 3, the service delivery gap; Gap 4, the marketing communication gap; and Gap 5, the perceived service quality gap (Arokiasamy \& Abdullah, 2013).

Gap 1 identifies the difference between the manager's perception of the customers' expectations, on the one hand, and the customers' actual needs and desires, on the other. It is important that managers accurately perceive customers' expectations.

Gap 2 identifies divergences in the specifications of service quality, where the manager may accurately identify the customers' needs but cannot translate that into the appropriate service specifications.

Gap 3 identifies those cases where quality specifications may be accurately identified but these specifications are not met in the delivery process.

Gap 4 identifies those cases where market communications promise services that are not delivered, and Gap 
5 identifies cases where the perceived service quality falls short of the customers' expectations (Zeithaml et al. 1990). All these gaps are important to a full understanding of service quality delivery in an organisation and, as can be seen from Figure 3, these are all intimately related.

This study focused on Gap 5 and in keeping with the conceptual framework identified in statement of problem. It sets out to identify where the perceived service quality fell short of the expectations of the customers whose was registered in the City Court.

A study conducted by Murillo et al (2014), entitled "Understanding The Service Quality Perception Gaps Between Judicial Servants And Judiciary Users" SERVQUAL's results have elicited that the main sources of users' dissatisfaction (defined as the difference between service users' expectations and perceived service quality) for the entire Costa Rican population of Judiciary service users were speed, accurate reporting upon service conclusion, service delivery within promised time, constant willingness to answer queries, performing well since the very beginning and genuine interest to provide a solution. Findings herein were found useful in further extending the latter reported results, as they actually suggest that Court's staff priorities are not focused on factors comprising the Capability and Response Speed Service Dimensions.

Research has consistently shown that the perceptions of those using the courts are influenced more by how they are treated and whether the process appears fair, than whether they received a favorable or unfavorable result. Thus, one of the important aspects of the quality approach and the 'search for excellence' is that it takes the needs and perceptions of Court customers into account. Court users include but may not be limited to members of the public and businesses making use of the services of the courts (e.g., litigants, witnesses, crime victims, those seeking information or assistance from court staff, etc.) and professional partners (lawyers, public prosecutors, enforcement agents, legal representatives of governmental agencies, court experts, and court interpreters). Accordingly, measures must address not only the level of satisfaction with the outcome of the court proceeding, but also the level of satisfaction with how the parties, witnesses, and lawyers were treated by the judges and the court staff; the (perceived) expertise of the judges and staff; and the fairness and understandability of court procedures and decisions

Justice, as a public service includes positive characteristics, as well as flaws, that are obvious to all users. Users develop a series of service delivery perceptions based on their personal experiences, information gathered from their surroundings and reactions to observed judicial system dysfunctions (López \& Zúniga, 2014, cited in Rodrigo, M., 2014.) Moreover, given the multiple and diverse stakeholders involved in judicial service delivery, i.e., plaintiffs and defendants, witnesses, victims, users and law professionals, there are different levels of expectations in terms of service quality. In this sense, Judiciaries must take on the responsibility for developing and promoting flexible and informal channels for judicial users to freely make suggestions on and complaints against, system or staff performance. This way, the judicial system would have a direct feedback mechanism supporting of sustainability and continuous improvement. If Judiciary service quality level is linked to users' satisfaction provided their real needs and expectations are taken into account, judicial system justices are responsible for reinforcing and assuring delivery of an 'acceptable' service quality level. Moreover, through provision of effective and efficient service to meet the needs of the public at large the government introduced the civil service reform program.

\section{METHODOLOGY OF THE STUDY}

\subsection{Research Design}

The study would be carried on the descriptive design in which both quantitative and qualitative data analysis were used to produce richer and more complete information. The reason behind using descriptive study design is because the researcher was interested in describing the existing situation under study. This study was also use explanatory study design, to explaining, understanding, predicting and controlling the relationship between variables and solve the research problem at hand, the study was used a SERQUAL model and some different statistical method to analyze the data. To determine the service quality \& customers' satisfaction levels related to the FIC \& AC, the study are used SERQUAL model; and to describe as well as to explore the satisfaction of the customer the study are uses summery statistics and logistic regression.

\subsection{Target Population}

The population of the study was all the customers served on the Dire Dawa City Courts First Instance Court and Appellate Court (FIC \&AC).

\subsubsection{Sampling Technique}

This study possessed the probability sampling techniques since the sampling units under the study have equal chance being a sample. There are four types of probability sampling technique, and among of those this study was used the stratified probability sampling techniques. Under stratified sampling, the population is divided into two subpopulations (strata) that are individually more homogeneous than the total population and then we select items from each stratum to constitute a sample. 


\subsubsection{Sample Size determination}

In conducting researches that require taking a sample, we always have the stage of deciding the sample size. Based on the above information, there are several formulas developed for sample size calculation that conform to different research situations. To determine the sample size and representative of the target population, the study was used statistical instrument formula. The following formula used for the calculation of the sample size since it is relevant to studies where a probability sampling method is used (Watson, 2001). The sample size of study computed as follows.

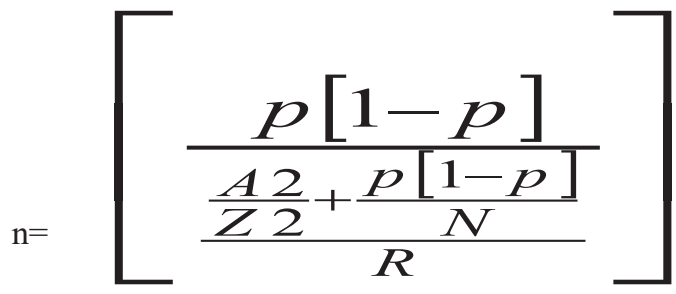

Where, $\mathrm{n}=$ sample size required $=290$

$\mathrm{N}=$ number of population $=1,400$

$\mathrm{P}=$ estimated variance in the population $=50 \%$

$\mathrm{A}=$ margin of error $=5 \%$

$\mathrm{Z}=$ confidence level $=1.96$ for $95 \%$ confidence

$\mathrm{R}=$ estimated response rate $=96 \%$

The proportional stratified sampling for each stratum will be determined by $\mathrm{n} / \mathrm{N}=290 / 1,400=0.20$ which means that $20 \%$ of each clusters as calculated in the table.

Table 3.1.The number of Sample size for each court with corresponding key informant

\begin{tabular}{lll}
\hline Key informant & Population & Sample 20\% \\
\hline First Instance Court & 700 & 140 \\
Appellate Court & 700 & 140 \\
Total Population & $\mathbf{1 , 4 0 0}$ & $\mathbf{2 9 0}$ \\
\hline
\end{tabular}

\subsection{Data Source}

Primary Data source are the actual customer those which would be get service on the Dire Dawa City courts. For instance, the actual customer is the person that would be getting the service in the First instance court and appellate courts from September, 2017 up to April, 2018. In addition to this, judges and registrar for federal courts and city courts, attorneys, public prosecutors and police were another primary source of data for the study. The secondary data sources included in the study are legislation, books \& journal, different organizational document, and articles. Particularly the literature for principles of judicial independence, principle case flow management and their essentiality for the efficient quality of courts, and access to justice were as a source of data.

\subsection{Type of Data and Collection Technique}

In order to achieve the intended objectives the data collection instruments was very important. The data of the study was quantitative (expressed in numerical form) and qualitative (expressed in the form of verbal descriptions rather than numbers).

\subsection{Variable of the study}

\subsubsection{Dependent variable (response variable):}

It is a variable which is depends upon or is a consequence of the other variable (variables).

$>$ Customer satisfaction

\subsubsection{Independent variable (explanatory variable):}

It is the variable that is antecedent to the dependent variable and also a variables that stand alone and not changed by other variable.

$>$ Demographic profiles of customers' (Age, Sex, Marital status, Educational level and Frequency for cases)

$>$ Tangibility

$>$ Reliability

$>$ Empathy

$>$ Responsiveness

$>$ Assurance

\subsection{Method of Data Analysis}

After gather, all necessary information the intended tools data processing and analysis would be properly 
implemented. The data was then processed using Statistical Packages for Social Sciences (SPSS) Software Version 23 and analysis methods included descriptive and inferential statistical techniques. Statistics analysis entails organizing data for description and decision-making. Depending on the data type, both descriptive and inferential statistics were used to analyze it.

\subsubsection{Inferential Statistics}

It describes the data with making inference or conclusion and summarizing sources of numerical data in to meaningful form. In this study chi-square test, SERVQUAL model and logistic regression were used.

\subsubsection{Logistic Regression}

The independent or predictor variables in logistic regression could be discrete, continuous or a mix of both. Logistic regression makes no assumption about the distribution of the independent variables. They do not have to be normally distributed, linearly related or have equal variance within each group. The model for logistic regression analysis assumes that the outcome variable $\mathrm{Y}$ is categorical. When we assume that $\mathrm{Y}$ is dichotomous, taking a values of 1 (that is, success, or satisfied customer) and 0 (that is, failure, or not satisfied customer).Then the conditional probability that the respondents are satisfaction of customer with judicial service delivery given the $\mathrm{X}$ set of predictor variables is denoted by

Prob $(\mathrm{Yi}=1 \mid \mathrm{X})=\mathrm{Pi}$. The expression Pi has the form:

$P_{i}=\frac{e^{\left(\beta_{0}+\beta_{1} x_{1 i}+\beta_{2} x_{2 i}+\cdots+\beta_{r} x_{1 i}\right)}}{1+e^{\left(\beta_{0}+\beta_{1} x_{1 i}+\beta_{2 i}+\cdots+\beta_{\mathrm{r}} x_{\mathrm{ri}}\right)}}=\frac{\mathrm{e}^{\mathrm{x}^{\prime} \beta}}{1+\mathrm{e}^{\mathrm{x}^{\prime} \beta}}$

$\mathrm{P}_{\mathrm{i}}=$ the probability of customer satisfaction on the service delivery for city court

$Y_{i}=$ the observed satisfaction of customer $\mathrm{i}$

$\beta$ is a vector of unknown coefficients.

The model given in the above is logistic regression model. The relationship between the predictor and response variables is not a linear function in logistic regression; instead, the logarithmic transformation of equation yields the linear relationship between the predictor and response variables. The logit transformation of $\mathrm{P}_{\mathrm{i}}$ given as follows: $\operatorname{logit}\left[P_{i}\right]=\log \left(\frac{P_{i}}{1-P_{i}}\right)=\beta_{0}+\beta_{1} x_{1}+\beta_{2} x_{2}+\cdots+\beta_{r} x_{r}$

Logistic regression is a form of regression, which is used when the dependent variable is dichotomous, such as satisfied (when the response is very high, high, and moderate) and not satisfied (if the response is low and very low). The logistic model is used to analyze and measure the level of satisfaction of customer towards on the judicial service delivery in probability (Agresti, 2007).

\subsubsection{Chi-square Test of Association}

Chi-square test of association are used to test the relationship between two categories exists or not. Which means it deals there is a significance association between the variable or not.

Model:

$X^{2}=\frac{\sum \sum\left(\mathrm{O}_{\mathrm{ij}}-\mathrm{E}_{\mathrm{ij}}\right)^{2}}{\mathrm{E}_{\mathrm{ij}}^{2}}$

Where:

$\mathrm{O}=$ observed count

$\mathrm{E}=$ expected count

The hypothesis:

H0: There is no significant relationship between service delivery and customer satisfaction.

H1: There is a significant relationship between service delivery and customer satisfaction.

\section{Data Analysis and Results}

\subsection{Response rate}

The survey was conducted between September, 2017 - April, 2018 questioners were distributed to 290 randomly chosen customers of First instance court and appellate courts of Dire Dawa City courts.

\section{Table 4.1: Response rate}

\begin{tabular}{lll}
\hline Participants & Frequency & Percentage \\
\hline Responded & $\mathbf{2 8 2}$ & $\mathbf{9 7}$ \\
Non responded & $\mathbf{8}$ & $\mathbf{3}$ \\
Total & $\mathbf{2 9 0}$ & $\mathbf{1 0 0}$ \\
\hline
\end{tabular}

Source: Survey2018

According to Table 4.1 above, out of the 290 questionnaires administered, 282 were returned fully completed, giving a response rate of $97 \%$ and 8 questionnaires were not returned giving a response rate of $3 \%$. The overall 
response rate of the respondents was thus $97 \%$.

\subsection{Demographic Profile}

From 282 study participants, $216(77 \%)$ were males and $66(23 \%)$ were females. This indicates that the males' respondents were more than that of female respondents. When we look at the age distribution of respondents, 227 $(80 \%)$ of the respondents were between the age of 18 to 40 years, 55(20\%) of them were above 40 years which implies majority of the respondents were among economically active population. (See Appendix 1)

\subsection{Reliability}

Cronbach's alpha reliability analysis was conducted on the independent variables in order to determine the reliability of the instrument used. Nunnally (1978) has suggested 0.70 as the acceptable level for reliability measure. Alpha values ranged from 0.767 to 0.867 , thus indicating an acceptable level of reliability.

Table 4. 2: Reliability Analysis

\begin{tabular}{lcc}
\hline \multicolumn{1}{c}{ Service Quality Dimensions } & No. Items & Cronbach's Alpha \\
\hline Tangibility & 4 & .767 \\
Reliability & 5 & .867 \\
Responsiveness & 4 & .860 \\
Assurance & 4 & .838 \\
Empathy & 5 & .783 \\
\hline
\end{tabular}

Source: Survey Result (2018),

\subsection{Factor Analysis}

According to Coakes and Steed (2007), Factor Analysis is a data reduction technique used to reduce a large number of variables to a smaller set of underlying factors that summarize the essential information contained in the variables. Factor Analysis is more frequently used as an exploratory technique when to achieve the objective of summarizing the structure of a set of variables. Before conducting factor analysis, items had been classifying into five domains, namely Tangible, Reliability, Responsiveness, Assurance and Empathy. Factor analysis was to run by using principle component analysis according to items in each domain across and components extracted by way of varimax rotation. Kaiser-Meyer- Olkin (KMO) is measure of sampling adequacy also examined to validate factor analysis, between the ranges of 0 to 1 , with 0.6 as the minimum level. The results of the Barlett's test were significant for all variables and KMO is the above-recommended value of 0.6 for all variables meaning that it indicates sampling adequacy.

Table 4.3: Kaiser-Meyer- Olkin (KMO)

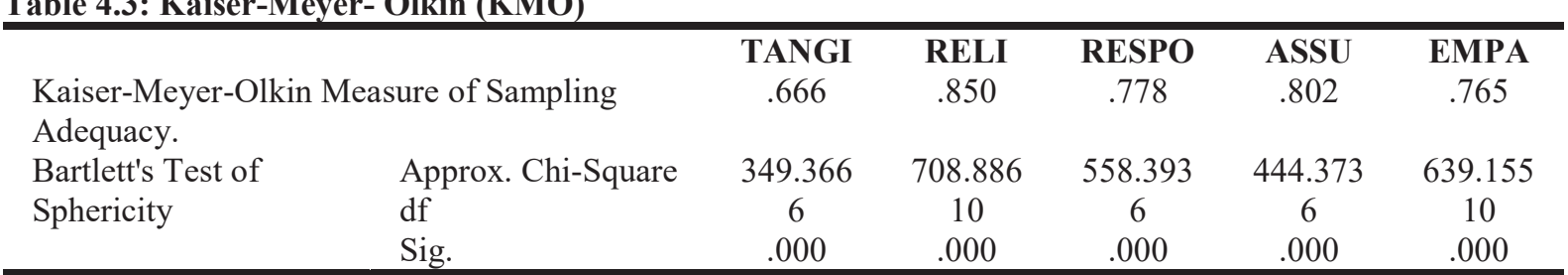

Source: Survey Result (2018), Tangible (TANGI), Reliability (RELI), Responsiveness (RESPO), Assurance (ASSU), Empathy (EMPA)

\subsection{Result of SERVQUAL Composite Score Analysis}

The various perceptions under each service quality dimension were grouped into five constructs and calculated its individual average to get composite scores. The modified version of SERVQUAL as proposed by Parasuraman et al., (1998) which involve five dimension of service quality is used to group the various perceptions of items and the composite scores were calculated. The table below shows the result of the service quality dimensions composite score. 
Table 4.4: Statically Analysis of Service Quality and Service Delivery

\begin{tabular}{lcccc}
\hline Dimension & $\begin{array}{c}\text { Perceived } \\
\text { Performance } \\
\text { Score }\end{array}$ & $\begin{array}{c}\text { Expectation } \\
\text { Performance } \\
\text { Score }\end{array}$ & $\begin{array}{c}\text { Gap Score } \\
\text { (perception - } \\
\text { expectation) }\end{array}$ & $\begin{array}{c}\text { Standard } \\
\text { deviation }\end{array}$ \\
\hline Tangibles & 3.33 & 4.37 & -1.0375 & 0.408 \\
Reliability & 3.67 & 4.46 & -0.798 & 0.236 \\
Responsiveness & 3.70 & 4.56 & -0.855 & 0.175 \\
Assurance & 3.64 & 4.51 & -0.865 & 0.056 \\
Empathy & 3.4 & 4.17 & -0.767 & 0.302 \\
Average of the composite scores & 3.548 & 4.414 & -0.4496 & \\
\hline
\end{tabular}

Source: Field survey 2018

\subsubsection{Service Quality Gap Analysis (Perceptions - Expectations)}

Expectations and perceptions were both measured using the 5-point Likert Scale whereby the higher numbers indicate higher level of expectation or perception. In general, consumer expectation exceeded the perceived level of service shown by the perception scores. This resulted in a negative gap score (Perception - Expectation). According to Parasuraman et al., (1988) it is however common for consumer's expectation to exceed the actual service perceived and this signifies that there is always need for improvement. From the table one can understand that the average score of customer expectations was mean value of 4.414 and the overall perception score was 3.548. The score shows a -0.4496 difference. This means that the expectations are higher than the perceived service quality. In general, the negative score for the SERVQUAL dimension were showed that there is a room for improving the City Courts service quality. As can be seen, the highest gap score were tangibility $(-1.0375)$ followed by assurance $(-0.865)$, responsiveness $(-0.855)$, reliability $(-0.798)$ and empathy $(-0.7675)$ of which the gap score in all dimension is pronounced and need attention from the service provider point of view.

\subsection{General Satisfaction Level of Customers}

On the other hand, customer were asked to rate their general level of satisfaction on service received at the City Courts in a single question and as the table 4.5 shows about $29.7 \%$ of respondents who rate their level of satisfaction as very high plus $33.36 \%$ of respondents rate their level of satisfaction as high and $9.576 \%$ respondents rate their level of satisfaction as moderate, the respondents think that the service meets their overall expectation and satisfaction $73 \%$. On the contrary, the rest $25 \%$ of respondents did not think that the service meet their expectation and unsatisfied; that is $10.64 \%$ of respondents rate that their level of satisfaction from the service they got is low plus $14.56 \%$ of respondents rate their level of satisfaction from the service they got is as very low.

Table 4.5: General Satisfaction Level

\begin{tabular}{llllllll}
\hline Perceived satisfaction & Very high & High & Moderate & Low & Very low & Missed & Total \\
\hline Count & 82 & 95 & 27 & 30 & 41 & 7 & 282 \\
Percent & 29.7 & 33.36 & 9.576 & 10.64 & 14.56 & 2.5 & 100 \\
\hline
\end{tabular}

Source: Field work, 2018

\subsection{The Relationship between Service Delivery and Customer Satisfaction}

The Chi-square test for association is used to discover if there is a relationship between two categorical variables. In other words, it tests whether or not a statistically significant relationship exists between a dependent and an independent variable. Where the dependent variable is the customer satisfaction in the City courts and the in dependent variable are the service delivery dimensions.

Table 4.6: The Chi-Square Tests Association between Service Delivery and Customer Satisfaction in Dire Dawa City Courts

\begin{tabular}{llllll}
\hline & Responsiveness & Tangibility & Reliability & Assurance & Empathy \\
\hline Chi-square & 37.425 & 28.762 & 44.825 & 56.033 & 30.228 \\
Df & 16 & 16 & 16 & 16 & 16 \\
Sig. & .002 & .026 & .000 & $.000^{*}$ & .017 \\
\hline
\end{tabular}

*. The Chi-square statistic is significant at the .05 level.

Source: Field work, 2018

The Chi-square statistics determines whether the observed values from the sample and expected values from the specified distribution are statistically different compared to the p-value (sig. value) to the significance level. Usually, a significance level (denoted as $\alpha$ or alpha) of 0.05 works well. A significance level of 0.05 indicates a $5 \%$ risk of incorrectly rejecting the null hypothesis.

Thus, P-value (sig.) $\leq \alpha$ : The observed data are statistically different from the expected values $\left(\right.$ Reject $\left.\mathrm{H}_{0}\right)$. In other word, If the p-value is less than or equal to the significance level, reject the null hypothesis and conclude 
that there was a significant association between the service delivery and the customer satisfaction in the City Courts. Therefore H1 is accepted. This implies that, the service deliveries of City Courts in the basis of five dimensions which are tangibility, reliability, responsiveness, assurance and empathy have significant association with the satisfaction of customer.

\subsection{The Logistic Regression}

Logistic regression is accepting quantitative, binary or categorical predictors and codes the latter two in various ways. Here's a simple model including a selection of variable types the criterion variable is satisfaction of customer on the service delivery of Dire Dawa City Courts and the predictors are responsiveness, tangibility, reliability, assurance, empathy, age, sex, marital status, education level and court frequency of delivering service in the city courts. But the following logistic regression table are includes some predictors which are uses for interpretation.

Table 4.7: Summery for Logistic Regression Output

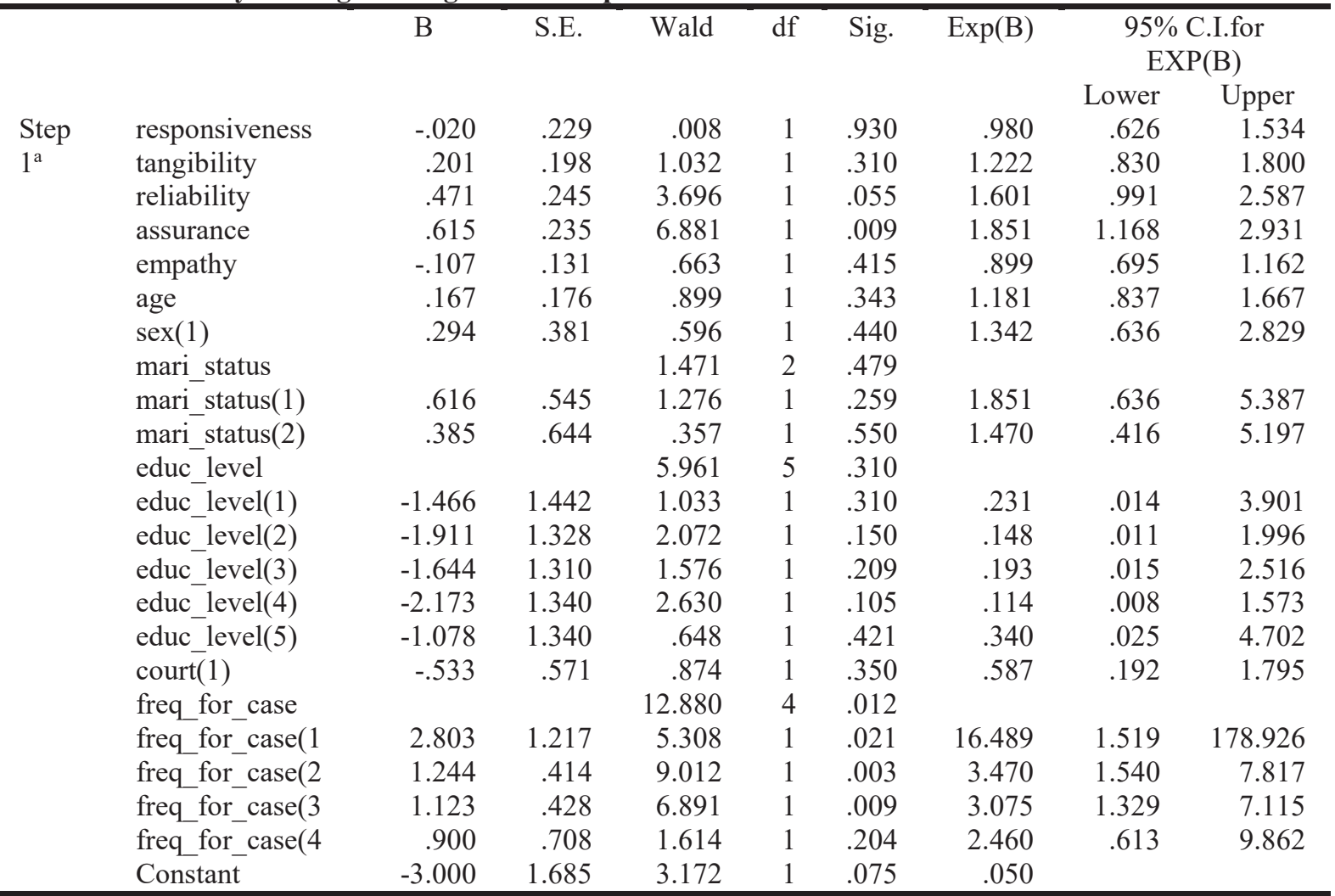

Source: survey result, 2018 function

The Logistic table is the most important one for our logistic regression analysis. It shows the regression

$$
\begin{aligned}
\operatorname{logit}\left(\frac{p}{1-p}\right) & =-3-0.02 x_{1}+0.201 x_{2}+0.472 x_{3}+0.615 x_{4}-0.167 x_{5}+2.803 x_{6} \\
& +1.244 x_{7}+1.123 x_{8}
\end{aligned}
$$

The table also includes the test of significance for each of the coefficients in the logistic regression model. For small samples the $\mathrm{t}$-values are not valid and the Wald statistic should be used instead. Wald is basically $\mathrm{t}^{2}$ which is Chi-Square distributed with $\mathrm{df}=1$. However, SPSS gives the significance levels of each coefficient. As we can see, reliability, assurance, frequency of the customer come in the court has significant effect and other variables are not.

These estimates tell you about the relationship between the independent variables and the dependent variable, where the dependent variable is on the logit scale. These estimates tell the amount of increase (or decrease, if the sign of the coefficient is negative) in the predicted log odds of satisfaction $=1$ that would be predicted by a 1 unit increase (or decrease) in the predictor, holding all other predictors constant. For the independent variables which are not significant, the coefficients are not significantly different from 0 , which should be taken into account when interpreting the coefficients. (See the columns labeled Wald and Sig. regarding testing whether the coefficients are statistically significant). Because these coefficients are in log-odds units, they are often difficult to interpret, 
so they are often converted into odds ratios. You can do this by hand by exponentiation the coefficient, or by looking at the right-most column in the Variables in the Equation table labeled "Exp(B)".

Reliability effect is positive, which means with a one unit increase on the five-point reliability scale being associated with the odds of customer satisfaction increasing by a multiplicative factor of 1.601. In other word, for every one-unit increase in reliability score (so, for every additional scale on the reliability), we expect a 1.601 increase in the log-odds of satisfaction of the customer, holding all other independent variables constant. Similarly, the effect of assurance on the satisfaction of customer in the city courts service delivery has positive effect. Thus, for every one-unit increase on the five-point assurance score, we expect a 1.851 increase in the log-odds of satisfaction, holding all other independent variables constant. For instance, when an increasing of the assurance dimension delivery in the city courts with one unit are yields $85 \%$ increment in the satisfaction of the customer. In addition, the frequency customers observed the City Court to get the service has also a positive effect for satisfaction of customer. Thus, the customer who observed the city courts up to two times to get services are 16.489 more likely to satisfy than frequency of served in the City Courts more than two times. In other word, when the customer have come to the Courts 'to get service more frequently yields a more un-satisfaction. Therefore, the logistic regression using 10\% significance level $(\mathrm{p}$-value $<0.01)$ the reliability, assurance and frequency to visit the city courts of the customer have positive effect on the satisfaction of customer. Thus, if the City Courts are provide more service on the reliability dimension, assurance dimension, and minimizing of visiting frequency to the customer would increase the satisfaction of customer.

\section{Conclusion}

The study was conducted to analyze service delivery and customer satisfaction in Dire Dawa City Courts. Gap analysis (disconfirmation approach) was employed to measure the service quality. Accordingly, a five dimensional instrument comprising of tangibility, reliability, responsiveness, assurance and empathy have been used for the study. The finding of the study showed a room for improvement for all dimension. The SERVQUAL result indicated that among the various service quality dimensions in the Courts responsiveness was the most important determinant of service quality followed by assurance, reliability, tangibles and empathy. Moreover, the SERVQUAL result depicted that responsiveness is the most important factor to have a positive and significant effect on customer satisfaction followed by reliability, assurance, empathy, and tangibility. The Chi-square test showed that, the five service quality dimensions (tangibility, responsiveness, assurance, empathy and reliability) were positively and significantly related with customer satisfaction. The overall satisfaction analysis result showed that $73 \%$ customers were satisfied by the City courts service. From the logistic regression, the City Courts are provide more service on the reliability dimension, assurance dimension, and minimizing of visiting frequency to the customer would increase the satisfaction of customer.

\section{Recommendation}

The following are recommendations from the research outcome

- The City court judges require supporting training (like on customer handling, jurisdictional power), seminars about cassation bench decisions, experience sharing with concerning body and so on are important to improve the satisfaction of customer and the competence of the judges. Similarly, registrar of the courts should be provided training on customers handling and management.

- Since customers have the highest expectations on responsiveness dimension of SERVQUAL model which shows it is the most important dimension of service quality for customers followed by assurance, the City Courts should work on responsiveness by giving trainings to employees to improve their ability to give prompt service, and willingness of the employees to help customers. It also improves the empathy dimension by training its employees to make them competent enough to deliver the service and to have the customer's best interest at heart.

- City Courts service delivery need due attention and improvement in the future on:

* Delivering service to customers in a fast manner and willingness to help customers

* Conveying confidence to customers and Judiciary's performance

* Individualized attention and offering customers personalized attention to improve customer satisfaction in the future

\section{REFERENCE}

Agrestie, A. (2007), An Introduction To Categorical Data Analysis, $2^{\text {nd }}$ Ed. New Jersey: John Wiley \& Sons, Inc.

Aghamolaei, T., Eftekhaari, T. E., Rafati, S., Kahnouji, K., Ahangari, S., Shahrzad, M. E., Hoseini, S. H. (2014). Service quality assessment of a referral hospital in Southern Iran with SERVQUAL technique: Patients' perspective. BMC Health Services Research, 14:322, 1-5. https://doi.org/10.1186/1472- 6963-14-322

Al Khattab, S. A., \& Aldehayyat, J. S. (2011). Perceptions of service quality in Jordanian hotels.International Journal of Business and Management, 6(7), 226-234. https://doi.org/10.5539/ijbm.v6n7p226

Almeida, R. S., Nogueira, L. A. C., \& Bourliataux-Lajoine, S. (2013). Analysis of the user satisfaction level in a 
public physical therapy service. Brazilian Journal of Physical Therapy, 17(4), 328-335. https://doi.org/10.1590/S1413- 35552012005000097

Andy, F. (2006). Discovering Statistic using SPSS. London: SAGE publication.

Arokiasamy, A. R. A., \& Abdullah, A. G. (2013). Service quality and customer satisfaction in the cellular telecommunication service provider in Malaysia. Journal of Arts, Science \& Commerce, 6(2), 1-9. Retrieved from http://www.researchersworld.com/vol4/ issue2/ Paper_01.pdf

Babakus, E. And Boller, G.W. (1992), “An Empirical Assessment of the SERVQUAL Scale”, Journal of Business Research, Vol 24

Bayraktaroglu, G., \& Atrek, B. (2010). Testing the superiority and dimensionality of SERVQUAL vs. SERVPERF in higher education. The Quality Management Journal, 17(1), 47-59. Retrieved from http://search.proquest.com.rproxy. uwimona.edu.jm/docview/ 213591799 ?accountid=42530

Bitner, Mary J. (1990), "Evaluating Service Encounters: The Effects of Physical Surroundings and Employees Responses" Journal of Marketing, Vol 54 Black's Law Dictionary, I979, $5^{\text {th }}$ ed.

Brysland, A., \& Curry, A. (2001). Service improvements in public services using SERVQUAL. Managing Service Quality: An International Journal, 11(6), 389-401. https://doi.org/10.1108/ 09604520110410601

Capacity Building Bureau (2013), The Civil Service Reform Program In Ethiopia, Addis Ababa, Ethiopia

Carman J. M. (1990), "Consumer Perceptions of Service Quality: An Assessment of the SERVQUAL Dimensions" Journal of Retailing, Vol 66, No.1

Carrillat, F. A., Jaramillo, F., \& Mulki, J. P. (2007).The validity of the SERVQUAL and SERVPERF scales: A meta-analytic view of 17 years of research across five continents. International Journal of Service Industry Management, 18(5), 472-490. https://doi.org/10.1108/09564230 710826250

Carvalho, C., Brito, C., \& Cabral, J. S. (2010). Towards a conceptual model for assessing the quality of public services. International Review on Public and Nonprofit Marketing, 7(1), 69-86. https://doi.org/10.1007/s12208-010-0046-5

Chakrapani, C. (1998). How to Measure Service Quality and Customer Satisfaction: The Informal Field Guide for Tools and Techniques. Chicago:American Marketing Association Chicago, IL

Charter of Dire Dawa Administration Proclamation No.416 /2004,

Chatzoglou, P., Chatzoudes, D., Vraimaki, E., \& Diamantidis, A. (2013). Service quality in the public sector: the case of the Citizen's Service Centers (CSCs) of Greece. International Journal of Productivity and Performance Management, 62(6), 583-605. https://doi.org/http://dx.doi.org/10.1108/ IJPPM-12-2012-0140

Crick, A. P., \& Spencer, A. (2011). Hospitality quality: New directions and new challenges. International Journal of Contemporary Hospitality Management, 23(4), 463-478. https://doi.org/ 10.1108/09596111111129986

Christoph G., (2011), Separation of Powers and the Independence of Constitutional Courts And Equivalent Bodies, Keynote Speech, $2^{\text {nd }}$ Congress of the World Conference On Constitutional Justice, Rio De Janeiro, P.1.

Coakes, S. J. and Steed, L. (2007). SPSS version 14.0 for windows: Analysis without Anguish, John Whiley and sons Australia, Australia

Collett D. (2002), Modeling Binary Data, Second Edition, Chapman \& Hall, CRC Press.

Cronin, J. Jr. And Taylor, S.A. (1992), "Measuring Service Quality: Re-Examination and Extension" Journal of Marketing, Vol 56

Cronin, J. J., \& Taylor, S. A. (1994). SERVPERF versus SERVQUAL; Reconciling performance-based and perceptions-minus-expectations measurement of service quality. Journal of Marketing, 58(1), 125-131. https://doi.org/10.2307/ 1252256Davis and Heineke (2003)

Deshwal, P. (2011). Service quality gap: A study of an engineering colleges part-time faculty perspective. In I. C. Torres, L. G. Chova and A. L. Martinez (Eds.), $4^{\text {th }}$ International Conference of Education, Research and Innovation (p. 4163). Madrid: ICERI.

Donnelly, M., \& Shiu, E. (1999). Assessing service quality and its link with value for money in a UK local authority's housing repairs service using the SERVQUAL approach. Total Quality Management, 10(4-5), 498-506. https://doi.org/10.1080/0954412997451

Donnelly, M., Kerr, N. J., Rimmer, R., \& Shiu, E. M. (2006). Assessing the quality of police services using SERVQUAL. Policing: An International Journal of Police Strategies \& Management, 29(1), 92-105. https://doi.org/10.1108/13639510610648502

Donnelly, M., Shiu, E., Dalrymple, J. F., \& Wisniewski, M. (1996). Adapting the SERVQUAL scale and approach to meet the needs of local authority services. In G. K.Kanji (Ed.), Total Quality Management in Action (pp. 263-266). Dordrecht, Netherlands: Springer International Publishing AG. https://doi.org/10.1007/978-94009-1543-5

Donnelly, M., Wisniewski, M., Dalrymple, J. F., \& Curry, A. C. (1995). Measuring service quality in local government: the SERVQUAL approach. International Journal of Public Sector Management, 8(7), 15-20. https://doi.org/10.1108/09513559510103157

Durvasula, S., Lysonshi, S., \& Madhavi, A. D. (2011). Beyond service attributes: Do personal values matter? 
Journal of Services Marketing, 25(1), 33-45. https://doi.org/ 10.1108/0887604111 1107041

Durvasula, S., Lysonski, S., \& Mehta, S. C. (1999). Testing the SERVQUAL scale in the business-to-business sector: The case of ocean freight shipping service. Journal of Services Marketing, 13(2), 132-150. https://doi.org/10.1108/0887 6049910266040

Dutta, K. \& Dutta, A. (2009), “Customer Expectations And Perceptions Across The Indian Banking Industry And The Resultant Financial Implications", Journal of Services Research, Vol.No.9, Issue.No. 1, pp.

Dyke, T. P., Prybutok, V. R., \& Kappelman, L. A. (1999). Cautions on the use of the SERVQUAL measure to assess the quality of information systems services. Decision Sciences, 30(3), 877-891. https://doi.org/10.1111/j.1540-5915.1999. tb00911.x

Eshghi A, Roy, S \& Guanguli, S. (2008), "Service Quality and Customer Satisfaction: An Empirical Investigation in Indian Mobile Telecommunication Services" Marketing Management Journal Vol 18 No.2

Ethiopian Management Institute, (2011), Capacity Building Workshop on Transformational Change Leadership and Service Delivery for Addis Ababa Administration Woreda Leaders, Addis Ababa, Ethiopia.

FDRE, Ministry Of Capacity Building, Comprehensive Justice System Reform Program Baseline Study Report, 2005.

Finn, D. W. D. W., \& Lamb, C. W. C. W. (1991). An evaluation of the SERVQUAL scales in a retailing setting. Advances in Consumer Research, 18(1), 483-490.

Gabbie O. and O'neill M. A. (1996) "SERVQUAL and the Northern Ireland Hotel Sector: A Comparative Analysis-Part 1" Managing Service Quality: An International Journal, Vol 6 Issue 6

Ghobadian A., Speller S. And Jones M. (1994) "Service Quality: Concepts And Models" International Journal Of Qaulity And Realibility Management, Vol 11 Issue:9

Gilbert, G. R., Veloutsou, C., Goode, M., \& Moutinho, L. (2004). Measuring customer satisfaction in the fast food industry: a cross-national approach. Journal of Services Marketing, 18(5), 371-383. https://doi.org/10.1108/0887 6040410548294

Golding, P. (2005). Jamaica foods group (JFG's) information systems service quality assessment. In Y. Levy (Ed.), Proceedings of the IEEE SoutheastCon 2005: Excellence in Engineering, Science, and Technology (pp. 507512). https://doi.org/10.1109/SECON.2005.1423295

Golding, P., Donaldson, O., Tennant, V., \& Black, K. (2008). An Analysis of Factors Affecting the Adoption of ICT By MSMES in Rural and Urban Jamaica. ECIS 2008 Proceedings Website, 237.

Golding, P., Tennant, V., \& Virtue, T.-A. (2011). Telecommunications in Jamaica: Monopoly to liberalized competition to monopoly (2000 - 2011). GlobalDev, 13, 1-14. Retrieved from http://aisel.aisnet.org/globdev2011/13

Govender, K. K. (2016). Exploring public transport service quality: The case of minibus taxi service in South Africa. Eurasian Business Review, 6(1), 101-116. https://doi.org/10.1007/s40821-015-0036-y Gow (2014)

Grönroos, C. (1984). A service quality model and its marketing Implications. European Journal of Marketing, $18(4), 36-44$.

Grönroos, C. (1990). Service Management and Marketing Theory, Managing the Moments of Truth in Service Competition. Lexington, MA, MA: Lexington Books.

Grönroos, C. (2000). Service Management and Marketing: A Customer Relationship Management Approach. New York, NY, NY: Wiley.

Grönroos, C. (2001). The perceived service quality concept-a mistake? Managing Service Quality, 11(3), 150152.

Hasik L., Yonki L., Dongkeunyoo, (2000), “The Determinants of Perceived Service Quality and Its Relationship with Satisfaction", Journal of Services Marketing, Vol.14 Issu.3

J.C. Nunnally. Psychometric theory (2nd ed.). New York: McGraw-Hill. 1978

J. G. Collier, (1973), "Conflict of Laws Jurisdiction Staying of Action, Forum Convention, Forum Shopping" The Cambridge Law Journal, Vol. 32, No. 1, Pp.49-52, P.52.

Johns, N., \& Tyas, P. (1996). Use of service quality gap theory to differentiate between foodservice outlets. Service Industries Journal, 16(3), 321-346. https://doi.org/10.1080/ 02642069600000031

Kilbourne, W. E., Duffy, J. A., Duffy, M., \& Giarchi, G. (2004). The applicability of SERVQUAL in cross-national measurements of health-care quality. Journal of Services Marketing, 18(7), 524-533. https://doi.org/10.1108/08876040410561857

Kothari, C.R. (2004), Research Methodology, $2^{\text {nd }}$ Ed., New Delhi: New Age International (P) Ltd

Kotler and Armstrong (2006),Principles of Marketing, 11th Edition

Ladhari R. (2009), “A Review of Twenty Years of SERVQUAL Research”, International Journal of Quality and Service Sciences, Vol 1 Issue 2 Pp172-198

Ladhari, R. (2008). Alternative measures of service quality: A review. Managing Service Quality. Vol. 18. https://doi.org/10.1108/09604520810842849

Lam, S. S. K., \& Woo, K. S. (1997). Measuring service quality: A test-retest reliability investigation of 
SERVQUAL. Journal of the Market Research Society, 39(2), 381-396. Retrieved from http://search.proquest.com.rproxy. uwimona.edu.jm/docview/214816526?accountid=42530

Lee, H., Lee, Y., \& Yoo, D. (2000). The determinants of perceived service quality and its relationship with satisfaction. Journal of Services, 14(3), 217-231. https:// doi.org/10.1108/08876040010327220

Liu, x. (2010). Ordinal Regression Analysis: Fitting the continuation Ratio Model to Educational Data Using Stata. North eastern Educational Research Association Annual conference (pp. 12-16). NERA.

McAlexander, J. H., Kaldenberg, D. O., \& Koenig, H. F. (1994). Service quality measurement. Journal of Health Care Marketing, 14(3), 34-40.

Murillo R. (2014), “Understanding The Service Quality Perception Gaps Between Judicial Servants And Judiciary Users" International Journal For Court Administration Vol 6 No.2

Musah, M. B., Ali, H. B. M., Al-Hudawi, S. H. V., Tahir, L. M., Daud, K. B., \& Hamdan, A. R. (2015). Determinants of students' outcome: A full-fledged structural equation modelling approach. Asia Pacific Education Review, 16(4), 579-589. https://doi.org/10.1007/s12564-015-9396-3

Ogunnowo, B. E., Olufunlayo, T. F., \& Sule, S. S. (2015). Client perception of service quality at the outpatient clinics of a General hospital in Lagos, Nigeria. Pan African Medical Journal, 22, 1-8. https://doi.org/10.11604/pamj.2015.22.68.6228

O’Neill M. And Palmer A, (2003), “An Explanatory Study of Effects of Experience On Consumer Perceptions the Service Quality Construct” Managing Service Quality: An International Journal Vol13 Issue 3, Pp 187-196

Oliver R.L. (1997), Satisfaction: A Behavioral Perspective on the Consumer.

Parasuraman, A, Zeithaml, VA and Berry LL (1985), “A Conceptual Model of Service Quality and Implications for Future Research" Journal Of Marketing, Vol. 49

Parasuraman, A., Zeithaml, V.A., and Berry, L.L. (1988), "SERVQUAL: A multiple- item scale for measuring consumer perceptions of service quality", Journal of Retailing, Vol. 64 No.1, pp. 12-40.

Parasuraman, A., Berry, L. L., \& Zeithaml, V. A. (1991a). Perceived service quality as a customer-based performance measure: An empirical examination of organizational barriers using an extended service quality model. Human Resource Management, 30(3), 335-364. Retrieved fromhttp://search.proquest.com/docview/224326681? accountid=42530

Parasuraman, A., Berry, L. L., \& Zeithaml, V. A. (1991b). Refinement and reassessment of the SERVQUAL scale. Journal of Retailing, 67(4), 420-450. https://doi.org/10.1111/j.1438-8677.2010.00335.x

Parasuraman, A., Berry, L. L., \& Zeithaml, V. A. (1993). More on improving service quality measurement. Journal of Retailing, 69(1), 140-147. https://doi.org/10. 1016/S0022-4359(05)80007-7

Parasuraman, A., Zeithaml, V. A., \& Berry, L. L. (1985). A conceptual model of service quality and its implications for future research. Journal of Marketing, 49(4), 41-50. https://doi.org/10.2307/1251430

Parasuraman, A., Zeithaml, V. A., \& Berry, L. L. (1988). SERVQUAL: A multipleitem scale for measuring consumer perceptions of service quality. Journal of Retailing, 64(1), 12-40. https://doi.org/10.1016/S01482963(99)00084-3

Parasuraman, A., Zeithaml, V. A., \& Berry, L. L. (1994). Alternative scales for measuring service quality - A comparative-assessment based on psychometric and diagnostic-criteria. Journal of Retailing, 70(3), $201-230$. https://doi.org/ 10.1016/0022-4359(94)90033-7

Rhee, S.-K., \& Rha, J.-Y. (2009). Public service quality and customer satisfaction: Exploring the attributes of service quality in the public sector. The Service Industries Journal, 29(11), 1491-1512. https://doi.org/10.1080/02642060902793441

Rida K., Dr. Hummayoun N., Sana E., Faiza M., Taha B. (2012), Service Quality and Customer Satisfaction in Public Transport Sector Of Pakistan: An Empirical Study, International Journal of Economics and Management Sciences, Vol. 1, No. 9.

Robinson S. (1999) "Measuring Service Quality: Current Thinking and Future Requirements" Marketing intelligence And Planning Vol 17 Issuel

Rocha, L. R. M., Veiga, D. F., de Oliveira, P. R., Song, E. H., Ferreira, L. M., (2013). Health service quality scale: Brazilian Portuguese translation, reliability and validity. BMC Health Services Research, 13(1), 24. https://doi.org/10.1186/ 1472-6963-13-24

Rodrigo, M., (2014), Understanding the Service Quality Perception Gaps between Judicial Servants and Judiciary Users, International Journal for Court Administration.

Roslan, N. A. A., Nor, N. M., \& Wahab, E. (2015). Service quality: A case study using SERVQUAL model. Advanced Science Letters, 21(6, SI), 2159-2162. https://doi.org/10.1166/asl.2015.6243

Schoburgh, E. D. (2014). Does local government have capacity for enabling local economic development? Lessons from Jamaica. Commonwealth Journal of Local Governance, (14), 3-22. Retrieved from http://epress.lib.uts.edu.au/journals/index.php/cjlg/article/view/4060/4114

The 1995 Federal Democratic Republic of Ethiopia (FDRE) Constitution of Ethiopia

The World Bank, (2004), Ethiopia: Legal and Judicial Sector Assessment. 
Vaughan, L., \& Shiu, E. (1999). “Archsecret”: A service quality model for the voluntary sector. In American Marketing Association (pp. 97-98). Glasgow: Glasgow Caledonian University.

Vaughan, L., \& Shiu, E. (2001). ARCHSECRET: A multi-item scale to measure service quality within the voluntary sector. International Journal of Nonprofit and Voluntary Sector Marketing, 6(2), 131-144. https://doi.org/10.1002/ nvsm.141

Van IwaardenJ.,Van Der Wiele, T. Ball, L.,\& Millen, R.( 2003) “Applying SERVQUAL To Websits: An Explanatory Study" International Journal Of Quality And Reliability Management, Vol 90 No. 8 Pp 919-935

Watson, Jeff. 2001. How to Determine a Sample Size: Tip sheet \#60, University Park, PA: Penn State Cooperative Extension.

Weekes, D. J., Scott, M. E., \& Tidwell, P. M. (1996). Measuring quality and client satisfaction in professional business services. Journal of Professional Services Marketing, 14(2), $25-37$. https://doi.org/10.1300/J090v14n02_03

Wisniewski, M. (2001a). Assessing customer satisfaction with local authority services using SERVQUAL. Total Quality Management, 12(7-8), 995-1002. https://doi.org/10.1080/09544120100000026

Wisniewski, M. (2001b). Using SERVQUAL to assess customer satisfaction with local authority services. Management Science Theory, Method \& Practice No. 2001/9. Glasgow.

Wisniewski, M. (2001c). Using SERVQUAL to assess customer satisfaction with public sector services. Managing Service Quality: An International Journal, 11(6), 380-388. https://doi.org/10.1108/EUM0000000006279

Wisniewski, M., \& Donnelly, M. (1996). Measuring service quality in the public sector: The potential for SERVQUAL. Total Quality Management, 7(4), 357-366. https://doi.org/10.1080/09544129650034710

World Bank (2004), Ethiopia: Legal and Judicial Sector Assessment. Washington, DC.

World Bank (2013), Ethiopia Public Sector Reform Approach: Building the Developmental State - A Review and Assessment of the Ethiopian Approach to Public Sector Reform.

Xianying, X., \& Qinhai, M. (2007). Improvement on the Method of Service Quality Gap Measurement. International Conference on Wireless Communications, Networking and Mobile Computing, Vols 1-15, pp. 3239-3242.

Yoo D.K. And Park J, (2007) "Perceived Service Quality: Analyzing Relationships among Employees, Customers, and Financial Performance" International Journal of Quality and Reliability Management, Vol 24 Issue 9 Pp 908-926

Zeithaml, Parasuraman and Berry (1990), "Five Imperatives for Improving Service Quality" Sloan Management Review

Zeithaml, V. \& Bitner, M (2003), Service Marketing: Integrating Customer Focus across the Firm.

Zeithaml, V., Bitner, M. \& Gremler, D. (2009), "Service Marketing: Integrating Customer Focus Across the Firm", 5th edn. Boston: McGraw International Edition.

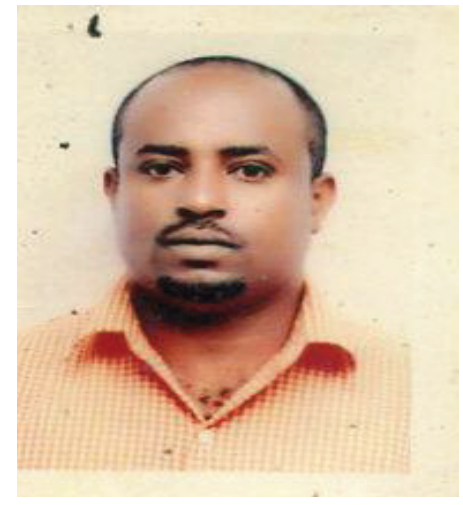

BINIYAM KEBEDE DESTA (MBA)

Lecturer of Management (Department Head of MBA)

Addis Ababa Medical and Business College

Dire Dawa, Ethiopia 


\begin{tabular}{|c|c|c|c|}
\hline & & & \\
\hline Measures & Items & Frequency & Percent \\
\hline \multirow{5}{*}{ Age } & Below and 24 & 70 & 24.8 \\
\hline & $25-29$ & 71 & 25.2 \\
\hline & $30-40$ & 86 & 30.5 \\
\hline & 41 and above & 55 & 19.5 \\
\hline & Total & 282 & 100.0 \\
\hline \multirow[b]{3}{*}{ Gender } & Female & 66 & 23.4 \\
\hline & Male & 216 & 76.6 \\
\hline & Total & 282 & 100.0 \\
\hline \multirow{7}{*}{ Education level } & Illiterate & 21 & 7.4 \\
\hline & Primary School & 60 & 21.3 \\
\hline & Secondary School & 102 & 36.2 \\
\hline & Diploma & 52 & 18.4 \\
\hline & First Degree & 41 & 14.5 \\
\hline & Above & 6 & 2.1 \\
\hline & Total & 282 & 100.0 \\
\hline \multirow[b]{4}{*}{ Marital Status } & MARRID & 173 & 61.3 \\
\hline & SINGLE & 83 & 29.4 \\
\hline & DIVORCED & 26 & 9.2 \\
\hline & Total & 282 & 100.0 \\
\hline \multirow[b]{3}{*}{ Customers served } & First Instant Court & 250 & 88.7 \\
\hline & Appellate Court & 32 & 11.3 \\
\hline & Total & 282 & 100.0 \\
\hline \multirow[b]{6}{*}{ Status of Customers served } & Plaintiff & 176 & 62.4 \\
\hline & Defendant & 86 & 30.5 \\
\hline & Other & 2 & .7 \\
\hline & Total & 264 & 93.6 \\
\hline & Missing & 18 & 6.4 \\
\hline & Total & 282 & 100.0 \\
\hline \multirow{7}{*}{ Frequency of the customer visited courts } & one to two times & 109 & 38.7 \\
\hline & two to five times & 83 & 29.4 \\
\hline & five to ten times & 16 & 5.7 \\
\hline & above ten times & 62 & 22.0 \\
\hline & Total & 270 & 95.7 \\
\hline & Missing & 12 & 4.3 \\
\hline & Total & 282 & 100.0 \\
\hline
\end{tabular}

Source: survey result, 2018 
Appendix 2: There are five dimensions in the SERVQUAL analysis, which is tangibility, reliability, responsiveness, assurance, and empathy questions.

\begin{tabular}{|c|c|}
\hline No & SERVQUAL dimensions \\
\hline \multicolumn{2}{|r|}{ Tangibles: physical facilities, equipment, and appearance of personnel } \\
\hline 1 & $\begin{array}{l}\text { Courts have modern equipment (computers, data capture systems, information systems provided to } \\
\text { customers) }\end{array}$ \\
\hline 2 & Courts’ facilities are visually attractive (waiting rooms, toilets, halls, etc) \\
\hline 3 & Courts staff has a neat personal appearance \\
\hline 4 & $\begin{array}{l}\text { The material elements related to service delivery used by Courts are visually attractive (signs, } \\
\text { informative posters, brochures, etc.) }\end{array}$ \\
\hline \multicolumn{2}{|r|}{ Reliability - Ability to perform service dependably and accurately } \\
\hline 1 & When courts promise to do something they do it \\
\hline 2 & When you have a problem, courts show a sincere interest to provide a solution \\
\hline 3 & Courts perform right since the very first time \\
\hline 4 & Courts provide their service within the promised time window \\
\hline 5 & Judiciary keeps error free records (case files, documents, etc) \\
\hline \multicolumn{2}{|r|}{ Responsiveness: willingness to help customers and provide prompt service } \\
\hline 1 & Judiciary's staff accurately informs customers when a service delivered, is going to end \\
\hline 2 & Judiciary's staff delivers service to customers promptly \\
\hline 3 & Judiciary's staff is always willing to help service Customers \\
\hline 4 & Judiciary's staff is never too busy to answer questions and resolve issues from service customers. \\
\hline \multicolumn{2}{|r|}{ Assurance: courtesy knowledge, ability of employees to inspire trust and confidence } \\
\hline 1 & Judiciary's staff behavior conveys confidence to service customers \\
\hline 2 & $\begin{array}{l}\text { You are confident of Judiciary's performance (documents handed in, consultations, verdict issued by a } \\
\text { judge, etc) }\end{array}$ \\
\hline 3 & Judiciary's staff always has a nice attitude towards you \\
\hline 4 & $\begin{array}{l}\text { Judiciary's staff is knowledgeable enough to answer the specific questions and consultations from } \\
\text { customers }\end{array}$ \\
\hline \multicolumn{2}{|r|}{ Empathy: Caring, and individualized attentions the Courts provide to their Customers } \\
\hline 1 & $\begin{array}{l}\text { Judiciary provides customers' an individualized attention (when service is being delivered is only } \\
\text { delivered to you) }\end{array}$ \\
\hline 2 & Judiciary’s opening hours are convenient to all customers \\
\hline 3 & $\begin{array}{l}\text { Judiciary's staff offers customers a personalized attention (service is adapted to the specific needs of } \\
\text { customers) }\end{array}$ \\
\hline 4 & Judiciary's staff does care about the interests of customers \\
\hline 5 & Courts understand customers specific needs \\
\hline
\end{tabular}

